\title{
Bcl-2-Like Protein 10
}

National Cancer Institute

\section{Source}

National Cancer Institute. BCl-2-Like Protein 10. NCI Thesaurus. Code C117140.

Bcl-2-like protein 10 (194 aa, $\sim 22 \mathrm{kDa}$ ) is encoded by the human BCL2L10 gene. This protein plays a role in the promotion of cell survival and the negative regulation of apoptosis. 